Genetic manipulation

\title{
Rifkin battle lost, war undecided
}

\section{Washington}

A PANEL of the US Court of Appeals has ruled invalid a lower-court injunction forbidding the National Institutes of Health (NIH) to approve any deliberate-release experiments (see Nature 312, 689; 1984). But the Lindow experiment on frostresisting bacteria is still held up pending approval of a formal document assessing its environmental risks.

The lower-court injunction, granted to anti-genetic-engineering activist Jeremy Rifkin, had ordered NIH's Recombinant DNA Advisory Committee (RAC) to prepare a lengthy "environmental impact statement" before considering any other proposals for field trials of recombinant organisms. NIH officials said that preparing such a document would have taken a year and would itself have been subject to further legal challenges.

The Lindow experiment, in which genetically-modified bacteria would be sprayed on potato plants to protect against frost damage, was to be the first in which bacteria containing recombinant DNA were to be released to the open environment. The experiment was approved by RAC in June 1983; in August of that year, Rifkin sued in federal court to halt it.

Although the appeals court has removed the biggest threat that Rifkin held over RAC - the prospect of tying up all deliberate release experiments in years of legal manoeuvring - it left no doubt that NIH did not follow the law in approving the Lindow experiment without first completing a formal environmental assessment. The court said that environmental assessments would likewise be required for each deliberate-release experiment that comes before RAC.

As for the Lindow experiment, it is now apparently up to the lower court in the person of District Court Judge John Sirica to decide whether the environmental assessment that the RAC staff has in fact just completed on the experiment is adequate. Rifkin's lawyer has raised the possibility of challenging that point. Rifkin himself has said on several occasions that he does not believe that there is at present sufficient knowledge fully to assess the environmental risks posed by the deliberate release of recombinant organisms.

The court's ruling also opens the way for routine legal challenges of every deliberaterelease experiment that comes before RAC on the grounds that the environmental assessment is inadequate.

NIH are meanwhile taking steps to get out of the business altogether. The Environmental Protection Agency (EPA) intends to regulate all field trials of "microbial pesticides" that have been genetically altered or manipulated; under new EPA rules, the agency would have to be given 90 days' notice of any such test.
(Previously, EPA regulations applied to field trials of pesticides only when the test plot exceeded 10 acres.)

EPA is also working on regulations that would apply to field trials of other recombinant organisms as well. At the next RAC meeting, scheduled for 3 May, the committee is expected to approve a proposal that would allow researchers subject to the RAC guidelines (currently any institution that receives federal funds for recombinant DNA activities) to go ahead with deliberate release experiments so long as they have approval from another federal agency; RAC approval would no longer always be required.

RAC has not received any new proposals for deliberate-release experiments from federally-funded institutions since the Lindow approval went to the courts. Two private companies, however, Advanced Genetic Sciences (which proposed an experiment virtually identical to Lindow's) and Cetus Madison (which proposed a plant experiment), voluntarily submitted proposals last year; RAC approved them, but the NIH director, James Wyngaarden, decided that even though the injunction did not apply to private companies (which are not legally bound by the RAC guidelines), there should be no double standards, so he is holding up approval until environmental assessments are prepared for them. Advanced Genetic Sciences has since withdrawn its proposals and has decided to deal only with EPA; Cetus Madison has been told that if it still wants its proposal considered by NIH, it should submit a draft environmental assessment.

Stephen Budiansky
THE following are extracts from the opinion of the United States Court of Appeals in the case in which NIH appealed from a ruling of the lower court awarding an injunction on deliberate-release experiments to the Foundation on Economic Trends, Mr Jeremy Rifkin's organization.

\section{Judge Wright}

This appeal presents an important question at the dawn of the genetic engineering age: what is the appropriate level of environmental review required of the National Institutes of Health (NIH) before it approves the deliberate release of genetically engineered, recombinant-DNA-containing organisms into the open environment?

We emphatically agree with the district court's conclusion that NIH has not yet displayed the rigorous attention to environmental concerns demanded by law. We therefore affirm the district court's injunction prohibiting the University of California deliberate-release experiment until an appropriate environmental assessment is completed. We also share the district court's view that NIH should give greater consideration to the broad environmental issues attendant on all deliberate release of organisms containing recombinant DNA, and to its own responsibility for approving these deliberate-release experiments. We find, however, that the part of the injunction enjoining NIH from approving all other deliberate-release experiments is, at this juncture, overly broad, and we therefore vacate the part of the injunction that prohibits NIH approval of those experiments. We emphasize, however, that if NIH fails to give appropriate environmental consideration to any other experiment, as it has failed to do with the University of California experiment, injunctive relief would be clearly proper.

Broad claims are made about both the potential benefits and the potential hazards of genetically engineered organisms. Use of recombinant DNA may lead to welcome advances in such areas as food production and disease control. At the same time, however, the environmental consequences of dispersion of genetically engineered organisms are far from clear.

\section{The Lindow experiment}

On September 17, 1982, Drs Lindow and Panopoulos, scientists at Berkeley, submitted a request for NIH approval of an experiment that would involve deliberate release of genetically altered organisms in the open environment. NIH approval was required because the University of California receives NIH funds for recombinant DNA research.

Neither the government nor the university seriously disputes that an environmental assessment is necessary. The university's contention here is that the environmental consideration given by $\mathrm{NIH}$ was equivalent to the necessary environmental assessment that the injunction requires only a document labelled "Environmental Assessment".

We thus fear that the university and the government completely misapprehend the district court's holding and the requirements imposed by NEPA [the National Environmental Policy Act]. The most glaring deficiency in NIH'sreview of the Lindow-Panopoulos experiment is its treatment of the possibility of dispersion of recombinant-DNA-containing organisms. An environmental assessment that fails to address a significant environmental concern can hardly be deemed adequate for a reasoned determination that an EIS [environmental impact statement] is not appropriate.

\section{NIH procedures}

The district court also found that plaintiffs were likely to succeed in showing that NIH should have completed an EIS (1) in 1978, when it revised the guidelines to make deli- 